\title{
JOURNAL.RU
}

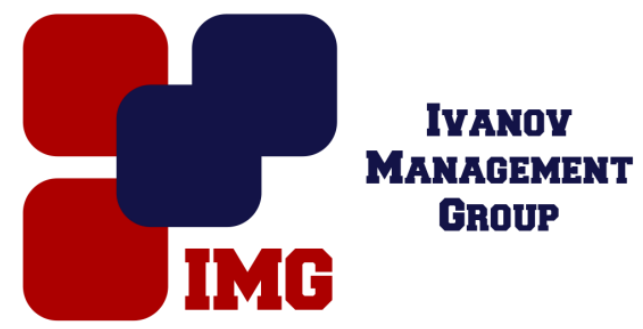

Дрожжин М.А. Институт подготовки государственных и муниципальных служащих Академии ФСИН России Рязань, Россия

doi: $10.18411 / 1 \mathrm{j}-31-05-2017-47$

idsp 000001:1j-31-05-2017-47

\section{Исторические предпосылки формирования института репутационного вреда в России}

История формирования института репутационного вреда достаточно небольшая, и сам институт продолжает формироваться в наши дни. Мы рассмотрим позиции законодателя, мнения ведущих правоведов и судебной практики во временном разрезе.

Отметим, что ни законодательство Российской Империи, ни тем более классическое советское законодательство не предусматривало нормы, которые бы предоставляли право юридическому лицу на компенсацию морального вреда. Поэтому, история законодательного регулирования берет свое начало в 1991 году с Основ гражданского законодательства Союза ССР и республик (далее Основы) и принятием Гражданского Кодекса РФ. Положения п.6 ст. 7 Основ и п.7 ст. 152 ГК РФ устанавливали, что правила этих статей о защите деловой репутации гражданина соответственно применяются к защите деловой репутации юридического лица. Буквально можно было толковать следующим образом - юридическое лицо, в отношении которого были распространены порочащие деловую репутацию сведения, вправе требовать наряду с опровержением возмещения убытков и морального вреда, причиненных распространением таких сведений. Многие отечественные правоведы придерживались позиции, что на самом деле законодатель не наделяет юридических лиц правом на компенсацию морального вреда, а все дело в неудовлетворительном уровне юридической техники законодательных актов. Правильным вариантом толкования они считали следующий: компенсацию 
морального вреда вправе требовать только граждане; юридические же лица вправе требовать исключительно возмещение убытков.

Впрочем, вышедшее Постановление Пленума ВС РФ от 20 декабря 1994 года №10 «Некоторые вопросы применения законодательства о компенсации морального вреда» было призвано отмести все сомнения по поводу толкования спорных норм. Верховный Суд РФ разъяснил, что, регулирующие компенсацию морального вреда в связи с распространением сведений, порочащих деловую репутацию гражданина, применяются и в случаях распространения таких сведений в отношении организации. Отметим, что Пленум ВС РФ не стал затрагивать правовую природу морального вреда юридического лица, ограничившись только ссылкой на положения п.7 ст.152 ГК РФ. Пленум ВС РФ подтвердил свою правовую позицию уже позднее в п.15 Постановления от 25 февраля 2005 года №3 3 "О судебной практике по делам о защите чести и достоинства граждан, а также деловой репутации граждан и юридических лиц".

У научной общественности позиция Верховного Суда РФ не нашла поддержки. Более того, Высший Арбитражный Суд РФ изложил свое мнение по этому вопросу в Постановлении Пленума Высшего Арбитражного Суда РФ от 1 декабря 1998 г.

Настоящими источниками зарождения такого способа защиты как компенсация репутационного вреда юридическим лицам стали статьи в российских юридических журналах в конце 1990-х - начале 2000-х.

В 1999 г. К.Голубев и С. Нарижний в журнале «Российская юстиция» публикую статью «Защита деловой репутации юридических лиц». Примечательна она тем, что в ней впервые в научном обороте использовался термин «нематериальный вред» и предложена идея компенсировать такой вред юридическому лицу.

В комментариях к ГК РФ Г.М. Резник говорил о том, что в гражданском законодательстве необходимо предусмотреть право юридического лица на компенсацию репутационного вреда, поскольку деловой репутации юридического лица зачастую причиняется вред, который не связан с убытками. Таким образом, Г.М. Резником было дано самостоятельное определение, которое отличалось от морального вреда, причиненного гражданину. Уже позже, Генри Марковичем была разработана идея и механизм компенсации репутационного вреда юридическим лицам.

B.B. Старженецким был опубликован перевод извлечения из Постановления Европейского суда по правам человека от 06.04.2000 по делу 
«Компания Комингерсол С.А. против Поругалии», где фигурировал термин «нематериальные убытки», который в дальнейшем перекочевал в судебноарбитражную практику. Пожалуй, следует согласиться с Е.В. Гавриловым в том, что использование данного термина в российском праве - нонсенс, нежели необходимость. Все дело в том, что имел место некорректный перевод с английского языка понятия «nonpecuniary damage», который было бы правильно трактовать как «вред, не поддающийся точному денежному исчислению».

Безусловно, велика роль в формировании института репутационного вреда Л.О. Красавчиковой, которая в 2001 году в Академическом юридическом журнале издала статью «Компенсация морального вреда субъектам экономической деятельности в случаях причинения вреда их деловой репутации». Еще не будучи судьей Конституционного суда РФ, Л.О. Красавчикова указывает, что законодатель ни в одной из статей ГК не раскрывает категории «моральный вред» применительно к юридическим лицам. Статья посвящена именно случаям причиненного вреда гражданам. Безусловно, эта статья ГК неприменима в отношении юридических лиц. Однако из этого не следует того, что юридическому лицу вообще невозможно причинить моральный вред. Последний, являясь разновидностью вреда неимущественного, может иметь свое собственное, отличное от упомянутого в ст. 151 ГК, содержание в тех случаях, когда речь идет не о гражданах, а о юридических лицах.

Можно утверждать, что теоретические идеи Л.О. Красавчиковой в 2003 году, когда она стала судьей Конституционного Суда РФ, получили официальный правоприменительный статус. Конституционный суд рассмотрел дело по жалобе В.А. Шлафмана на нарушение п.7 ст.152 ГК РФ. Определение РФ от 04.12.2003 N 508-О (далее - Определение N 508-О) говорит нам о следующем: «отсутствие прямого указания в законе на способ защиты деловой репутации юридических лиц не лишает их права предъявлять требования о компенсации убытков, в том числе нематериальных, причиненных умалением деловой репутации, или нематериального вреда, имеющего свое собственное содержание (отличное от содержания морального вреда, причиненного гражданину), которое вытекает из существа нарушенного нематериального права и характера последствий этого нарушения». Очевидно, что позиция Л.О. Красавчиковой о необходимости компенсации морального (неимущественного) вреда - вреда который имеет отличное от упомянутого в статье 151 ГК РФ 
содержание, прослеживается в данном определении. Впрочем, напрямую о возможности компенсации юридическому лицу морального вреда не говорится.

Определение №508-О стало краеугольным камнем в вопросе возможности нести юридическим лицом материальные убытки. Рассмотрим основные позиции, сформировавшиеся в отечественном праве.

Первая группа правоведов, во главе с С.В. Потапенко, полагает, что юридическое лицо может испытывать как моральный так и репутационный вред. Причём репутационный вред юридическое лицо может испытывать только в случае, если соответствующие нарушения имели место быть при осуществлении организацией экономической и предпринимательской деятельности, тогда как моральный вред юридическое лицо может претерпевать в отношениях, не имеющих имущественную и экономическую окраску.

Вторая группа юристов, в частности К.И. Скловский, С.Кузин, полагает, что для юридического лица не свойственно испытывать никакой вред - ни моральный, ни репутационный, ни какой-либо другой нематериальный.

Третья группа, к последователям которой относятся И.В. Цветков, Э.А. Цадыкова, Н.Козлова, придерживаются позиции, что юридическое лицо не может испытывать морального вреда, однако оно вправе требовать компенсации вреда репутационного для защиты своих нематериальных благ (прежде всего деловой репутации). Проанализировав мнения всех трех групп ученых, представляется верным остановиться именно на третьей.

На сегодняшний день законодатель не дает нам ответы на такие вопросы как: «что понимать под нематериальным вредом?», «что есть репутационный вред?», «за что необходимо взыскивать компенсацию?». Необходимо нормативное разъяснение данных положений, которое ляжет в основу уже существующей судебной практике по данным вопросам. Пока его нет представляется верным использовать доктринальные идеи, возникающие по этому поводу.

Е.В. Гавриловым в 2008 году было разработано и апробировано во время устных выступлений с докладами на международных юридических научнопрактических конференциях следующее определение: «моральный вред юридическому лицу - это его нематериальный вред, то есть неблагоприятные последствия нематериального характера, которые не поддаются точному исчислению, являются отрицательными и существенными для юридического лица, а также привели или могут привести к возникновению убытков, представляющих собой материальное выражение вреда». 
Более 20 лет российское законодательство предоставляло возможность взыскивать моральный вред в пользу юридического лица. Подход законодателя изменился с 1 октября 2013 года. В положения статьи 152 ГК РФ внесены изменения, исключающие взыскивать моральный вред за нарушение репутации юридического лица. Исходя из этого, следует разумный вывод - законодатель посчитал, что моральный вред несовместим с природой юридического лица.

Несмотря на исключение из ст.152 ГК РФ нормы о возможности взыскания морального вреда в пользу юридических лиц, правовая позиция Конституционного Суда РФ, выраженная в Определении №508-О, не утратила своей правовой силы. Таким образом, налицо противоречия, которые не позволяют однообразно решить спор о возможности или невозможности взыскания морального вреда в пользу юридического лица.

В качестве примера рассмотрим дело № А50-21226/2014, рассмотренное Экономической коллегией ВС РФ. Интересно заключается в том, что оно было рассмотрено после внесения изменений в ст. 152 ГК РФ. Арбитражный суд удовлетворил исковые требования истца о возмещении морального вреда, тем самым проигнорировав изменения в ГК от 1 октября 2013 года и поддержав позицию Конституционного Суда РФ. Экономическая Коллегия ВС РФ, в свою очередь, отменила решение арбитражного суда и отказала в удовлетворении иска, признав выводы, приведенные в решении ошибочными. Аргументация была следующей: из буквального содержания ст. 152 ГК РФ следует, что компенсация морального вреда возможна в случаях причинения такого вреда гражданину действиями, нарушающими его личные неимущественные права либо посягающими на принадлежащие гражданину другие нематериальные блага. В иных случаях компенсация морального вреда может иметь место лишь при наличии прямого указания об этом в законе. Поскольку в действующем законодательстве отсутствует прямое указание на возможность взыскания морального вреда в пользу юридического лица, в связи с чем, оснований для удовлетворения заявленных требований не имелось.

Можно смело утверждать, что требования о денежном возмещении репутационного (нематериального) вреда встречаются почти в каждом исковом заявлении, которое юридические лица подают в арбитражный суд для защиты деловой репутации. Тем интереснее будет следить за формированием данного института в гражданском праве. 
1. Гаврилов Е.В. "Нематериальные убытки" в российском праве: нонсенс или необходимый юридический термин? // Арбитражная практика. 2009. №10. С. 3 - 14.

2. Гаврилов Е.В. Состав субъектов при компенсации нематериального (репутационного) вреда // Адвокат. 2009. N 3. С. 27 - 28.

3. Защита деловой репутации в случаях ее диффамации или неправомерного использования (в сфере коммерческих отношений): Научно-практ. пос./М.А.Рожкова, М.Е.Глазкова, Д.В.Афанасьев - М.: Статут, 2015-270 с

4. Иваненко Ю.Г. Деловая репутация юридических лиц и ее правовая защита // СПС "Гарант".

5. Каменева 3.В. Деловая репутация как объект гражданского права // Адвокат. 2014. N 5; СПС "КонсультантПлюс"

6. Красавчикова Л.О. Компенсация морального вреда субъектам экономической деятельности в случаях причинения вреда их деловой репутации // Академический юридический журнал. 2001. N 2. С. $41-45$

7. Рожкова М.А. Новеллы Гражданского кодекса Российской Федерации: расширен ли круг объектов гражданских прав // Хозяйство и право. 2014. N 3. С. 11.

8. Фроловский Н.Г. Защита деловой репутации юридического лица // Законы России: опыт, анализ, практика. 2012. N 4 (СПС "КонсультантПлюс")

9. Эрделевский А.М. Защита чести, достоинства и деловой репутации в судебной практике // СПС "КонсультантПлюс". 